\title{
Revisiting Renewable Energy Map in Indonesia: Seasonal Hydro and Solar Energy Potential for Rural Off-Grid Electrification (Provincial Level)
}

\author{
Ruri Agung Wahyuono, ${ }^{1, *}$, and Miga Magenika Julian ${ }^{2,3}$ \\ ${ }^{1}$ Engineering Physics Department, Institut Teknologi Sepuluh Nopember, Keputih, Sukolilo, Surabaya, \\ 60111, Indonesia \\ ${ }^{2}$ Geodesy and Geomatics Engineering Department, Institut Teknologi Bandung, Lebak Siliwangi, \\ Coblong, Bandung, 40132, Indonesia \\ ${ }^{3}$ Institut Für Geographie, Friedrich-Schiller-University, Löbdergraben 32, 07743 Jena, Germany
}

\begin{abstract}
Regarding the acceleration of renewable energy diffusion in Indonesia as well as achieving the national energy mix target, renewable energy map is essential to provide useful information to build renewable energy system. This work aims at updating the renewable energy potential map, i.e. hydro and solar energy potential, with a revised model based on the global climate data. The renewable energy map is intended to assist the design off-grid system by hydropower plant or photovoltaic system, particularly for rural electrification. Specifically, the hydro energy map enables the stakeholders to determine the suitable on-site hydro energy technology (from pico-hydro, micro-hydro, mini-hydro to large hydropower plant). Meanwhile, the solar energy map depicts not only seasonal solar energy potential but also estimated energy output from photovoltaic system.
\end{abstract}

Key words: Hydro energy, solar energy, off-grid, rural electrification.

\section{Introduction}

Renewable energy is becoming a global issue as the crisis of fossil energy emerged nowadays. Indonesia as a part of the international community shares the concern on the environment and development issues [1-3]. Indonesia is a country with vast natural resources and significant reserves in oil, gas and coal. It is also abundant in reserves of renewable energy sources. There is also an enormous potential to develop and use clean energy sources such as hydropower (75 $000 \mathrm{MW})$, geothermal (29 164 MW), biomass (49 810 $\mathrm{MW})$, ocean (46 GW), solar $\left(4.80 \mathrm{~kW} \mathrm{~h} \mathrm{~m}^{-2} \mathrm{~d}^{-1}\right)$, and wind energy $\left(3 \mathrm{~m} \mathrm{~s}^{-1}\right.$ to $\left.6 \mathrm{~m} \mathrm{~s}^{-1}\right)$ [1-5].

*Corresponding author: ruri.tf014@gmail.com, miga.m.julian@gmail.com 
Despite these facts, Indonesia is currently facing an energy crisis. The average rate of energy consumption is approximately $7 \%$ in the last decade, while the rate of energy supply is limited. Indonesia is heavily dependent on fossil fuel, particularly on oil. Oil dominates of $50 \%$ of the primary energy mix, followed by coal at $32 \%$, gas at $19 \%$, geothermal at $1.3 \%$, hydro at $2.9 \%$ and the rest is supplied by other renewable energy resources $[2,3]$. Moreover, the high growth of fossil energy consumption will lead to environmental problems, particularly in high $\mathrm{CO}_{2}$ emissions that cause global warming.

Recently, the government of Indonesia committed to reducing greenhouse gasses (GHG) emissions up to $29 \%$ in 2030 through domestic efforts and $41 \%$ with international assistance $[1,2,6]$. Clean energy utilization, termed as renewable energy utilization and energy efficiency according to Presidential Regulation No. 4 and No. 5 year 2010 [1-4] is one of the priority activities in reducing GHG emission in the energy sector: National energy policy involves energy conservation and energy diversification to increase the share of new and renewable energy use in the national primary energy mix. Furthermore, energy mix target focuses to establish $17 \%$ new and renewable energy in energy mix (with an assumption of energy elasticity less than one in 2025 to optimize new renewable energy sources) [2, 3]. To date, the total installed capacity of national electricity is $30941 \mathrm{MW}$, with $83 \%$ electricity supplied by the national electricity company (PT. PLN), and the rest by the independent power producers (IPP) at $14 \%$ and private power utility at $3 \%$ [1]. Also, it is estimated that around $93 \%$ of Indonesia's inhabitants have access to electricity.

Despite the fact of high electrification ratio achieved in 2017, several areas, i.e. coastal and rural area, are facing electricity crisis with electricity demand higher than the supply or no electricity supply into these areas [6]. Since rural areas often face difficulties to get access to national electricity grid due to economic and geographical barriers, utilization of renewable energy resources is likely the only option for generating electricity [6, 7]. Moreover, in order for national energy mix target to achieve acceleration of renewable energy utilization whose technologies are technically and economically proven should be prioritized [6-9]. However, it is known that the renewable energy potential is site-specific and intermittent and hence, temporal (or seasonal) and spatial data of renewable energy potential is required to map the feasible energy generation and the selection of renewable energy technology at different sites. Herein the revised maps of renewable energy potentials, particularly hydro and solar energy, based on the global climate data to support the stakeholders of renewable energy development in Indonesia are presented.

\section{Method}

\subsection{Geographical and climatological data}

Data used for this study originated from secondary sources. Climate was represented by precipitation, air temperature, and sunshine duration. Climate data has been obtained from University of East Anglia Climate Research Unit (CRU) (CRU Climatology version 2.0CRU CL 2.0) [10]. These data provide the mean monthly precipitation, air temperature, and sunshine duration at a $(10 \times 10)$ min spatial resolution. The precipitation and air temperature were used for hydrological simulation and later to estimate the hydropower, whilst the sunshine duration was used to estimate the solar power.

Land cover was collected from The Global Land Cover by National Mapping Organizations (GLCNMO) developed by Geospatial Information Authority of Japan (GSI) and Chiba University, Japan. The data were prepared by using MODIS data in a grid of 500 $\mathrm{m}$ [11]. The heterogeneous land cover was converted into crop factor which was later used 
to calculate soil water holding capacity and potential evapotranspiration for hydrological modelling simulation.

The digital elevation model (DEM) was used $30 \mathrm{~m}$-Shuttle Radar Topography Mission (SRTM). The DEM was used to generate slope, river network model, and the natural falling head. For hydrological modelling, DEM should be pre-processed. As the presence of sinks (a pixel value lower than the surroundings) and peaks (a pixel where no adjacent pixels are higher) in DEM might result in an erroneous river flow direction raster, they were filled to ensure proper delineation of river basins and river networks. This step removed small imperfections in the data. After DEM corrected from sinks and peaks, the next step is deriving flow direction. The method of deriving flow direction from a DEM is based on literature [12]. Flow direction was determined by the direction of steepest slope from each cell. Flow direction determined the direction in which water would flow out of the pixel. The accumulated flow was based on the number of pixels that flowing into each pixel. Output pixels with a high flow accumulation were areas of concentrated flow and were used to identify the river network model. In summary, the schematic representation of geographical and climatological data collection and processing is depicted in Figure 1.

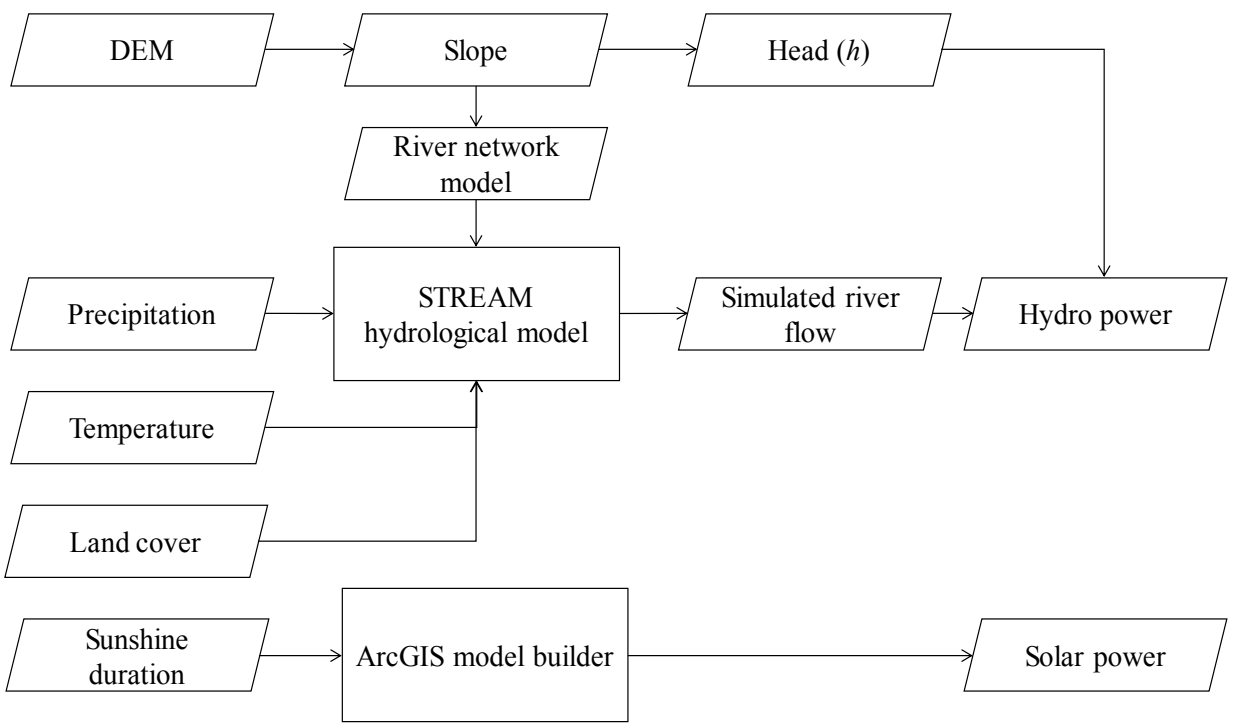

Fig. 1. Flow diagram of global climate data collection and processing for hydro and solar energy estimation.

\subsection{Estimation of hydro energy output}

Hydro power is classified by the net power output from the system. Typically, hydropower can be classified into picohydro, microhydro, minihydro, small, medium and large hydropower. In order to assess the net power output of the employment hydro energy potential was calculated using the following formula:

$$
E_{\text {hydro }}=\eta_{G} \times \eta_{T} \times \rho \times \dot{\forall} \times g \times h
$$

Where $\eta_{G}$ is the efficiency of generator, $\eta_{T}$ is the efficiency of hydro-turbine, $\rho$ is the density of water $\left(\mathrm{kg} \mathrm{m}^{-3}\right), \dot{\forall}$ is the volumetric flow rate $\left(\mathrm{m}^{3} \mathrm{~s}^{-1}\right)$, g is the gravitational acceleration $\left(9.8 \mathrm{~m} \mathrm{~s}^{-2}\right)$, and $\mathrm{h}$ is the falling height, head $(\mathrm{m})$. It should be noted that the hydro energy potential estimation in this study doesn't consider the energy sources from 
hydro kinetic energy. The $\eta_{G}$ spans from 0.85 to 0.93 , while the $\eta_{T}$ spans from 0.75 to 0.95 depending on the type of the turbine used in the system.

The $\dot{\forall}$ was assumed as river discharge flow in drainage network. $\dot{\forall}$ was simulated based on hydrological modelling. STREAM hydrological model is used. STREAM [13] describes the hydrological cycle of a drainage basin as a series of storage compartments and flows. It applies Thornthwaite-Mather's water balance approach to calculate flow discharges along drainage networks derived from a DEM. The main inputs to the model are climate data (maps of precipitation and temperature), a DEM, land cover maps and water holding capacity maps. Potential and actual evapotranspiration are calculated in STREAM at the so-called soil compartment represented by a grid cell. Following this, storage of water in a grid cell is estimated according to the difference between evapotranspiration and precipitation. Finally, discharge per time step is calculated according to excess of water in each grid cell and baseflow from groundwater storage. Calibration of STREAM model has been successfully done and documented in literature $[14,15]$. The $h$ is estimated based on the different elevation between two pixels on digital elevation model. Firstly, the slope map is generated from the DEM, later the tangent of slope in degree is used to estimate the rise (different height) over the run (spatial resolution of the DEM).

\subsection{Estimation of solar energy output}

Estimation of solar energy is employed in ESRI ArcGIS version 10 model builder. This allows us for calculating solar power in spatial-temporal scale. The daily energy output $\left(E_{P V}\right)$ of photovoltaic $(\mathrm{PV})$ system in this study was revised. In general, the daily energy output from a PV array is calculated using peak hours formula as below:

$$
E_{P V}=\frac{P_{\text {rated }} \times S}{\Phi_{A M 1.5 G}}
$$

Where $P_{\text {rated }}$ is rated peak power of PV panel (Wp), $S$ is insolation ( $\mathrm{kW} \mathrm{h} \mathrm{m}{ }^{-2}$ per day), and $\Phi_{A M 1.5 G}$ is radiative power flux at peak sun $\left(\mathrm{W} \mathrm{m}^{-2}\right)$. This formulation means that a PV panel receives constant $S / \Phi_{A M 1.5 G}$ peak hours of sun per day (a square-wave function). However, this leads an overestimation of the energy output from PV array since power conversion efficiency of PV declines at lower irradiation. Therefore, the radiative power flux in this work was modelled as a Gaussian wave instead of a square wave.

\section{Results and discussion}

As a tropical country, the seasonal variation in this work is discussed in the wet and the dry season which occurs approximately from October to March and from April to September, respectively. Therefore, the results of renewable energy potential map are simplified into two maps, i.e. the wet and the dry season.

The hydro energy potential is distributed in a manner as shown in Figure 2. It is again worth to note that hydro energy potential estimation neglects the kinetic energy potential by the water flow, instead it is determined from a classical approximation of potential energy due to the natural falling height $h$. Furthermore, the estimated hydro energy potential is used to classify the hydropower plant suitable at certain sites: picohydro $(<5 \mathrm{~kW} \mathrm{~h})$, microhydro ( $5 \mathrm{~kW}$ h to $100 \mathrm{~kW} \mathrm{~h}$ ), minihydro (100 $\mathrm{kW}$ h to $1 \mathrm{MW} \mathrm{h})$, small hydropower ( $1 \mathrm{MW} \mathrm{h}$ to $25 \mathrm{MW} \mathrm{h}$ ), medium hydropower (25 MW h to $100 \mathrm{MW} \mathrm{h}$ ) and large hydropower (>100 MW h) plant [16]. The topographical map of the falling head $h$ based on the digital elevation data is depicted in Figure 2a and the hydro energy distribution maps are shown in Figure 2b and Figure 2c. 


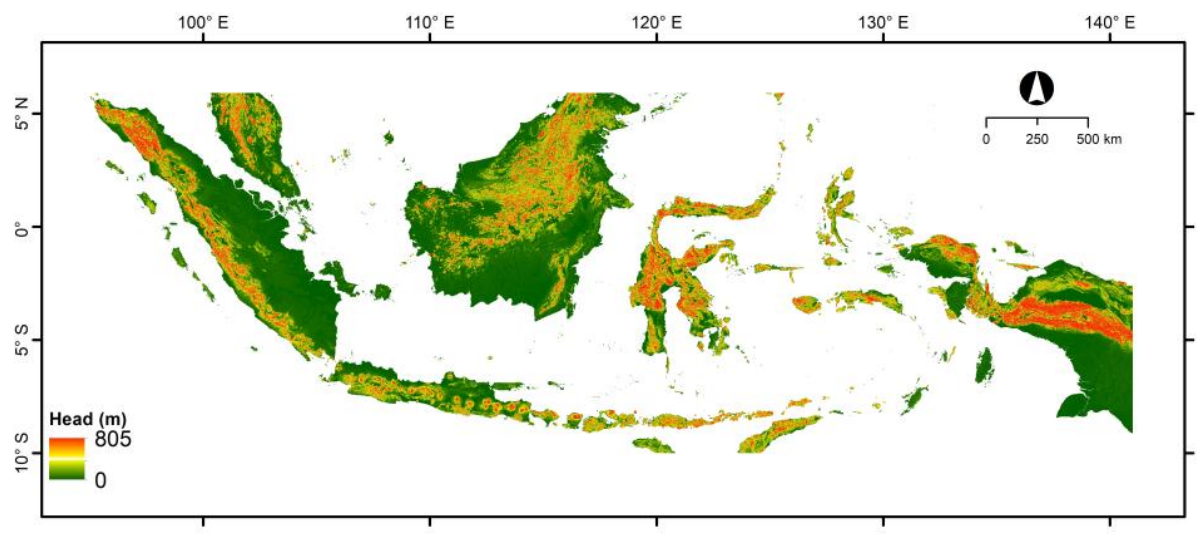

(a)

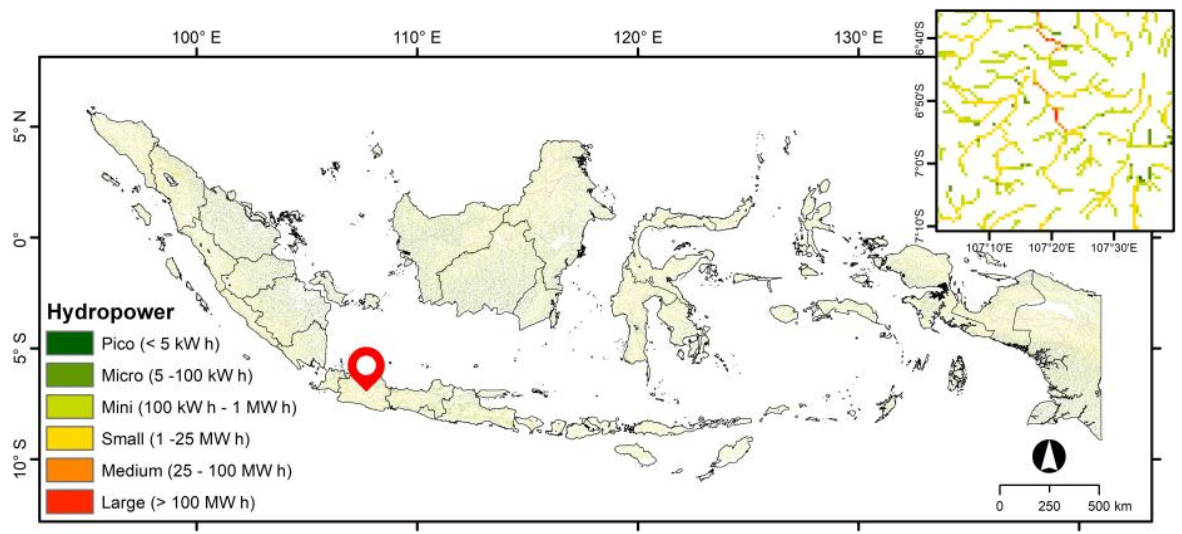

(b)

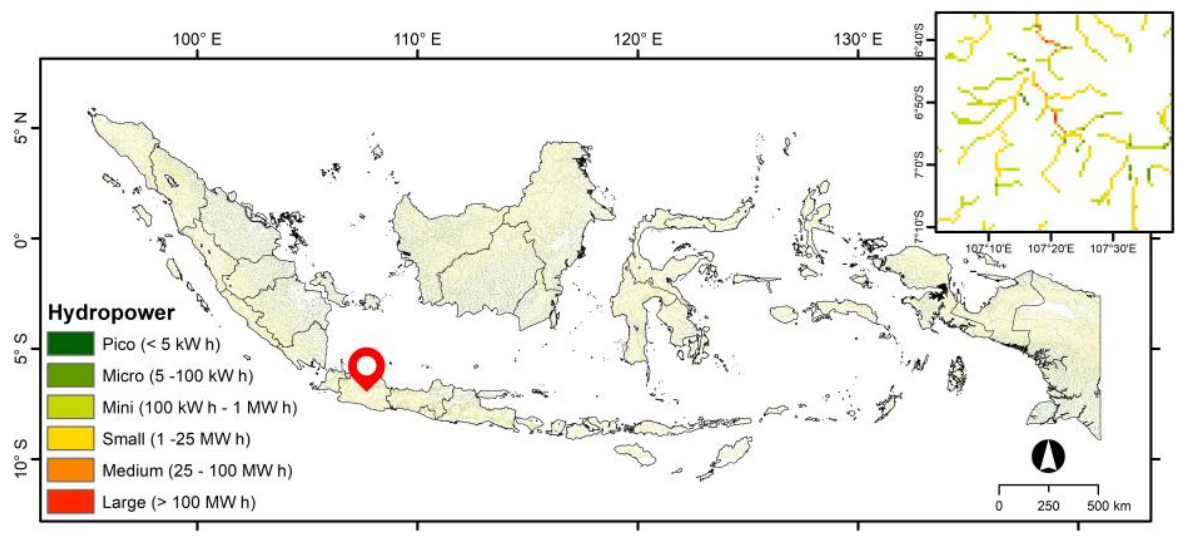

(c)

Fig. 2. (a) Head profile based on digital elevation data. Seasonal hydro energy potential during (b) wet and (c) dry season. Inset of figures depicts an enlarged map of hydropower distribution in west Java as indicated by location symbol (red) in the map. 
As shown in the above maps, the hydro energy potential in Indonesia is dominated by the pico to minihydro power plant. A more clear view on how the hydro energy potential changes due to seasonal change in west Java is indicated in the inset of Figure $2 b$ and Figure 2c. The estimated hydro energy potential in this study is verified by other reported works which shows the potential of developing micro and mini hydropower plant $[17,18]$. For example, Anugrah et al. [19] evaluating the microhydro power plant in West Sumatera with a capacity of $30 \mathrm{~kW}$ to $40 \mathrm{~kW}$ in which their system can be improved to yield an annual hydropower spanning from $170 \mathrm{MW}$ h to $275 \mathrm{MW} \mathrm{h}$. Meanwhile, other study by Kumara et al. [20] reports that $43.2 \mathrm{~kW}$ h hydropower can be generated in Bali where the hydro energy potential is lower than that in West Sumatera.

Large hydropower plants are only identified in five big islands in Indonesia. The order of the most potential locations is the following: Kalimantan (eastern, middle, and western part), Papua (eastern and middle part), Sulawesi (southeast and middle part), Sumatera (northern and western part), Java (western and middle part). This finding is in good agreement with the study reported by Purwanto and co-workers [21]. The study has concluded that $60 \%$ of total hydropower potentials are located in Kalimantan and Papua. The combination of the high river flows from the large watersheds, especially in the large island, and the variation of topographic slope generates abundant hydropower potential.

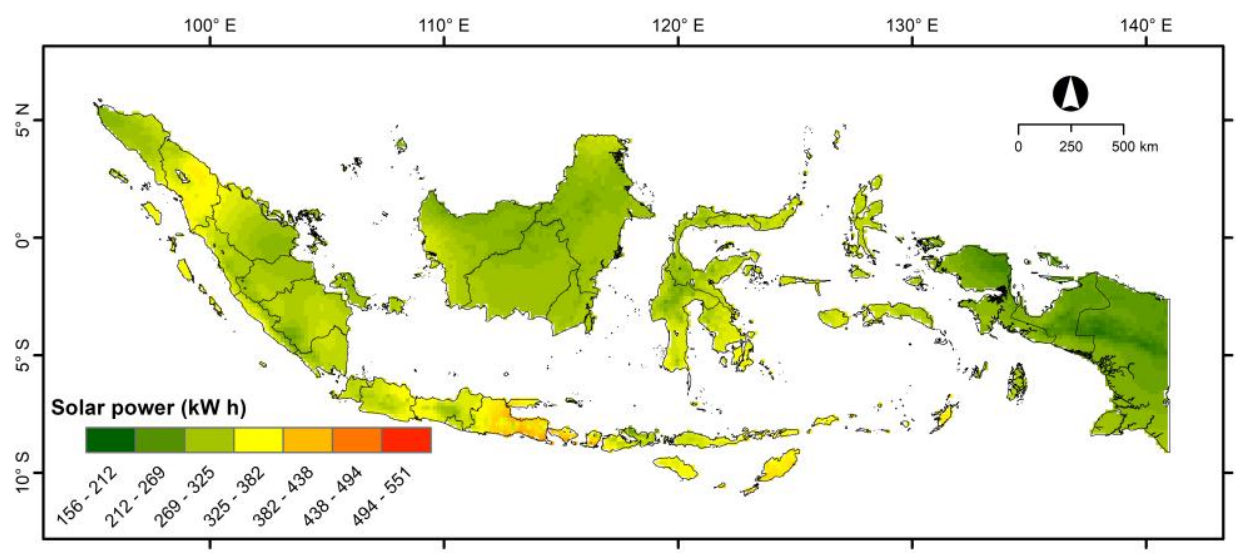

(a)

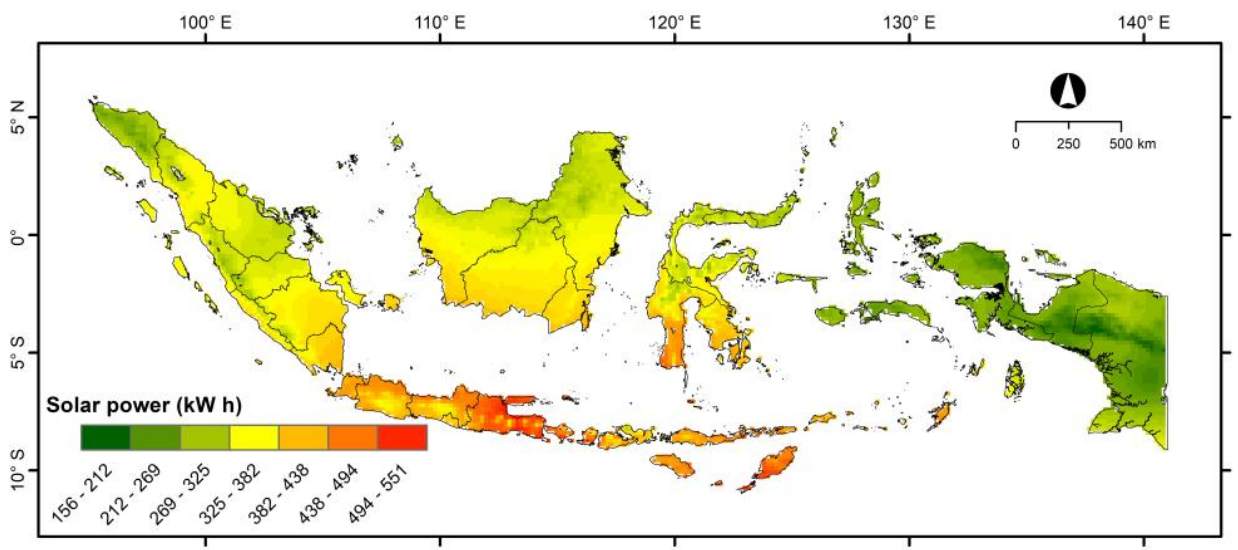

(b)

Fig. 3. Profile of estimated solar energy potential in Indonesia during (a) wet and (b) dry season. 
The central attention is now turned to the distribution of solar energy potential in Indonesia. In general, solar energy potential in Indonesia is distinguished into two different areas: The Western part of Indonesia features with an average irradiation of (4.50 \pm 0.45$)$ $\mathrm{kW} \mathrm{h} \mathrm{m} \mathrm{m}^{-2}$ per day and the Eastern part of Indonesia is characterized by an average irradiation of $(5.10 \pm 0.45) \mathrm{kW} \mathrm{h} \mathrm{m}^{-2} \mathrm{~d}^{-1}[8,9]$. In this work, the solar irradiation is spatially-varying from (1.3 to 3.6$) \mathrm{kW} \mathrm{h} \mathrm{m}^{-2}$ per day (data not shown) and slightly lower than that reported by Rumbayan et al. [22] and Veldhuis and Reinders [23]. The monthly solar irradiation also does not vary significantly within the same season and fluctuates in a moderate extent thought the year.

Figure 3 presents the profile of solar energy available in terms of practical solar energy potential: The solar irradiation potential is already converted into solar energy potential generated in full PV-battery system occupying $350 \mathrm{Wp} \mathrm{PV}$ module in $100 \mathrm{~m}^{2}$ area (DC/AC inverter's efficiency is set to 0.85 ). As seen in Figure 3, the availability of the solar energy can be used to prioritize the sites for renewable energy development. Some literatures claim that the eastern parts of Indonesia are exposed more solar irradiation than the western part, but the results here indicate that the reported solar energy potential distribution is only partially true. Some of the western were found, i.e. south Sumatera, south Kalimantan (Borneo) and Java island, and mid-eastern parts of Indonesia, i.e. Bali, East and West Nusa Tenggara, South Sulawesi, have the most stable annual solar-energy potential.

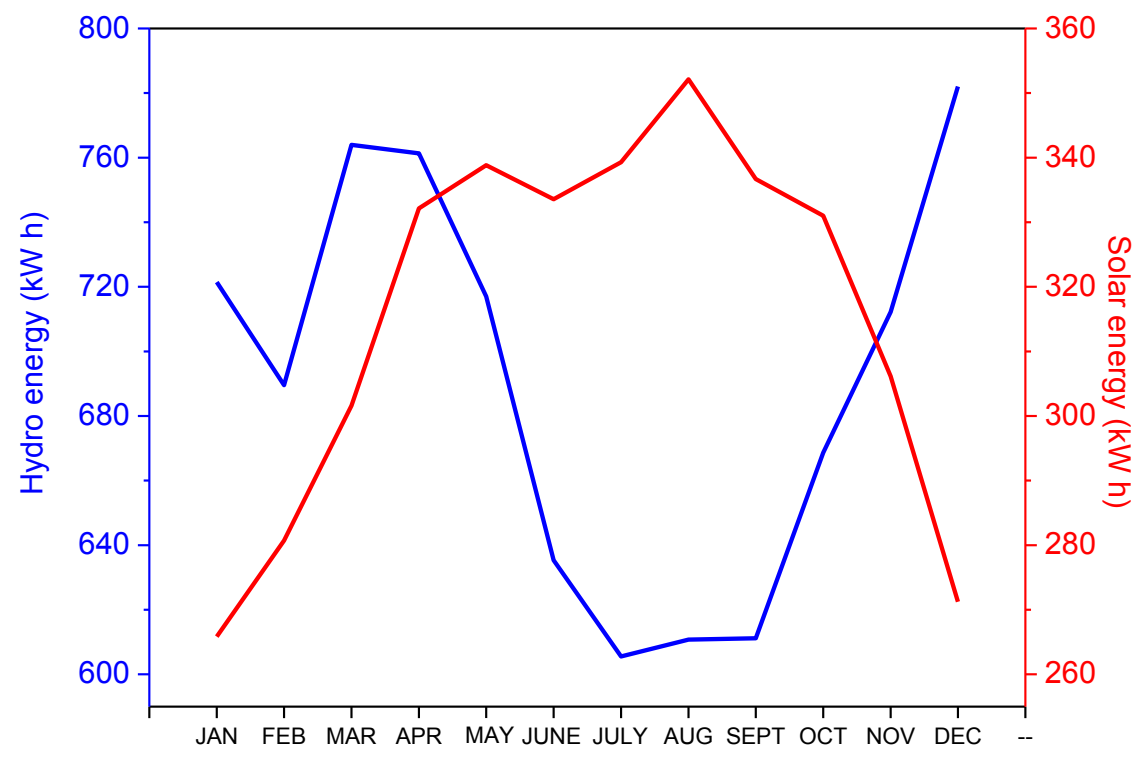

Fig. 4. Monthly potential energy output for hydropower and solar power generation at national level.

The monthly hydro and solar energy potential at national level is shown in Figure 3. It can be clearly seen that the hydro energy potential is lower $((620 \pm 10) \mathrm{kW} \mathrm{h})$ during the dry season (approximately starting from May to October), and in contrary the solar energy potential is at the highest level $((335 \pm 5) \mathrm{kW} \mathrm{h}))$ during the dry season. Overall, the results show that seasonal variation is not the case for solar energy potential in Indonesia, whilst the hydro energy potential is slightly affected by the seasonal change. Taking the integral of each renewable energy potential in a year, the dry to wet season ratio of total energy for hydro and solar energy is $42: 58$ and $54: 46$, respectively. 
Table 1. Hydro and solar energy potential at provincial level during the wet and the dry season.

\begin{tabular}{|c|c|c|c|c|}
\hline \multirow{2}{*}{ Province } & \multicolumn{2}{|c|}{ Hydropower (kW h) } & \multicolumn{2}{|c|}{ Solar power $(k W h)$} \\
\hline & Wet & Dry & Wet & Dry \\
\hline Aceh Darussalam & 7780 & 5168 & 300 & 293 \\
\hline Bali & 1133 & 875 & 399 & 491 \\
\hline Bangka Belitung & 108 & 92 & 295 & 373 \\
\hline Banten & 1595 & 1219 & 313 & 436 \\
\hline Bengkulu & 2390 & 2129 & 299 & 351 \\
\hline Central Java & 1663 & 1377 & 333 & 436 \\
\hline Central Kalimantan & 5664 & 4008 & 281 & 361 \\
\hline Central Sulawesi & 7219 & 5714 & 302 & 345 \\
\hline East Java & 1310 & 1013 & 374 & 492 \\
\hline East Kalimantan & 12791 & 9021 & 280 & 337 \\
\hline East Nusa Tenggara & 2510 & 1518 & 355 & 466 \\
\hline Gorontalo & 3698 & 2707 & 307 & 317 \\
\hline Jakarta & 515 & 368 & 317 & 451 \\
\hline Jambi & 3487 & 2976 & 295 & 338 \\
\hline Lampung & 1614 & 1313 & 305 & 387 \\
\hline Maluku & 2895 & 1654 & 301 & 291 \\
\hline North Maluku & 1862 & 1279 & 317 & 288 \\
\hline North Sulawesi & 2859 & 2289 & 321 & 307 \\
\hline North Sumatra & 4980 & 3526 & 336 & 335 \\
\hline Papua & 18348 & 10901 & 245 & 251 \\
\hline Riau & 2452 & 1965 & 305 & 331 \\
\hline South East Sulawesi & 4788 & 3186 & 330 & 398 \\
\hline South Kalimantan & 1813 & 1519 & 288 & 381 \\
\hline South Sulawesi & 7760 & 6288 & 306 & 380 \\
\hline South Sumatra & 1725 & 1468 & 301 & 365 \\
\hline West Java & 2531 & 2303 & 329 & 427 \\
\hline West Kalimantan & 5412 & 3713 & 283 & 356 \\
\hline West Nusa Tenggara & 1413 & 818 & 331 & 423 \\
\hline West Papua & 6491 & 3825 & 260 & 256 \\
\hline West Sumatra & 3877 & 3398 & 313 & 334 \\
\hline Yogyakarta Special Region & 1571 & 1302 & 310 & 397 \\
\hline
\end{tabular}

The hydro and solar energy potential distribution in provincial level is listed in Table 1. The results above support the current government action plan, for example the establishment of solar energy power plant in Nusa Tenggara. In fact, East Java shows promising solar energy to harvest but the availability of area for PV power plant limits the 
development of large PV system. The levelized cost of (renewable) energy utilizing hydro and solar energy is comparable with the electricity price from PLN. Kumara et al [20] reported that the micro-hydropower plant built in Bali allows the consumer to afford electricity with reasonable price of USD 0.5 per $\mathrm{kW}$ h. Furthermore, the use of off-grid PV systems is considered cheaper and profitable than generating electricity by using diesel generator or hybrid diesel/PV system.

\section{Conclusion}

In this paper, the potential of hydro and solar energy in Indonesia is mapped for predicting off-grid system utilizing renewable energy resources. The present results highlight the seasonal variation of hydro and solar energy potential in Indonesia and show that solar energy potential in Indonesia is stable throughout the year. The hydro energy potential enables mostly the development of hydropower plant in the scale of pico to minihydro. Meanwhile, the solar energy distribution reported here presents a higher and more stable energy potential in Java island, particularly in East Java, than in eastern part of Indonesia which is partially different to the literature. This implies that a thorough calculation and estimation is required for future revised solar energy map.

Financial support by Deutscher Akademischer Austauschdienst (DAAD), funding program No.: 57048249 is gratefully acknowledged.

\section{References}

1. E. Wibowo. Policies and strategies for the development of waste to energy in Indonesia. Ministry of Energy and Mineral Resources of the Republic of Indonesia, Directorate General of New Renewable Energy and Energy Conservation. 13 November (Jakarta, 2014). http://www.unescap.org/sites/default/files/Session\%202_3_MEMR.pdf

2. R. Mulyana. Government's policy on energy efficiency and renewable energy in buildings. Director General of New Energy, Renewable Energy and Energy Conservation. Presented at Conference on Energy Efficiency and Renewable Energy Solutions for Building, 31 May 2016 (Jakarta, Indonesia, 2016). http://indonesien.ahk.de/fileadmin/ahk_indonesien/Business_Delegations/Energy_Effic iency/Government_s_Policy_on_Energy_Efficiency_and_Renewable_Energy_in_Buil dings.pdf

3. Ministry of Energy and Mineral Resources Republic of Indonesia. Handbook of energy and economic statistics of Indonesia. Jakarta: Ministry of Energy and Mineral Resources Republic of Indonesia (2015). pp? https://www.esdm.go.id/assets/media/content/content-handbook-of-energy-economicstatistics-of-indonesia-2015-uwe2cqn.pdf

4. R.A. Wahyuono, M.N. Hakim, S.A. Santoso. Energy Procedia 65:324-330 (2015). https://www.sciencedirect.com/science/article/pii/S1876610215000612

5. A. Reinders, H. Veldhuis, A. Susandi. Development of grid-connected PV systems for remote electrification in Indonesia. The 37th IEEE Photovoltaic Specialists Conference (PVSC), 19-24 June, 2011 (Seattle, WA, USA, 2011). http://ieeexplore.ieee.org/document/6186437/ 
6. M.H. Hasan, W.K. Muzammil, T.M.I. Mahlia, A. Jannifar, I. Hasanuddin, Renew.

Sust. Energ. Rev., 16(5):3206-3219 (2012).

https://www.sciencedirect.com/science/article/pii/S1364032112000871

7. J. Hanafi, A. Riman. Procedia CIRP 29:444-449 (2015). https://www.sciencedirect.com/science/article/pii/S2212827115004734

8. R.A.Wahyuono. Dye-Sensitized Solar Cells (DSSC) fabrication with TiO2 and $\mathrm{ZnO}$ nanoparticle for high conversion efficiency. [Master Thesis]. Institut Teknologi Sepuluh Nopember, Indonesia (2013). p. 1.

https://www.researchgate.net/publication/273955833 Dye-

Sensitized_Solar_Cells_DSSC_Fabrication_with_TiO2 and $\mathrm{ZnO}$ Nanoparticle for_H igh_Conversion_Efficiency

9. A.J. Veldhuis, A.H.M.E. Reinders. Renew. Sust. Energ. Rev., 27:315-324 (2013). https://www.sciencedirect.com/science/article/pii/S1364032113003870

10. M. New, D. Lister, M. Hulme, I. Makin, Clim. Res. 21:1-25 (2002). https://crudata.uea.ac.uk/cru/data/hrg/tmc/new et al_10minute_climate_CR.pdf

11. R. Tateishi, N.T. Hoan, T. Kobayashi, B. Alsaaideh, G. Tana, D. Xuan Phong, Journal of Geography and Geology 6(3):99-122 (2014). http://www.cr.chiba-u.jp/ tateishilab/pdf/2014/GLCNMO2008JGG.pdf

12. S.K. Jenson, J.O. Domingue. Photogrammetric Engineering Remote Sensing 54(11):1593-1600 (1998).

http://citeseerx.ist.psu.edu/viewdoc/download?doi=10.1.1.138.6487\&rep=rep1\&type= pdf

13. J.C.J.H. Aerts, M. Kriek, M. Schepel, Physics and Chemistry of the Earth Part B: Hydrology, Oceans and Atmosphere 24(6): 591-595 (1999).

https://www.sciencedirect.com/science/article/pii/S1464190999000490

14. R. Poerbandono, P.J. Ward, M.M. Julian. ITB Journal on Engineering Science 41, 1:50-64 (2009). http://journal.itb.ac.id/index.php?li=article detail\&id=331

15. M.M. Julian, F. Nishio, Poerbandono, P.J. Ward, International Journal of Technology 2(1):37-46 (2011). http://www.ijtech.eng.ui.ac.id/old/index.php/journal/article/view/44

16. W.W. Purwanto, N. Afifah. Renew. Energy 93(C):312-322 (2016) https://econpapers.repec.org/article/eeerenene/v_3a93_3ay_3a2016_3ai_3ac_3ap_3a31 2-322.htm

17. Darmawi, R. Sipahutar, S.M. Bernas, M.S. Imanuddin, Renew. Sust. Energ. Rev., 17:213-215 (2013).

https://www.sciencedirect.com/science/article/pii/S1364032112005072

18. S. Murni, T Urmee, J. Whale, D. Harries. The implementation of micro hydro projects in remote villages on the border of Indonesia and Malaysia: Lessons learnt.

International Conference and Utility Exhibition 2014 on Green Energy for Sustainable Development, 19-21 March 2014 (Pattaya, Thailand, 2014).

http://ieeexplore.ieee.org/document/6828956/

19. P. Anugrah, A.A. Setiawan, R. Budiarto, Sihana. Energy Proc. 65:257-263 (2015).

https://www.sciencedirect.com/science/article/pii/S1876610215000442

20. Kumara, D.P.D. Suparyawan, W. G. Ariastina, W. Sukerayasa, I.A.D. Giriantari. Microhydro powerplant for rural area in Bali to generate green and sustainable electricity. International Conference on Smart Green Technology in Electrical and Information Systems (ICSGTEIS) 5-7 November 2014 (Bali, 2014). IEEE, pp. 113117. http://ieeexplore.ieee.org/document/7038741/ 
21. W.W. Purwanto, Y.S. Nugroho, R. Dalimi, A.H. Soepardjo, A. Wahid, D. Supramono, et al. Indonesia energy outlook and statistics. Jakarta: PEUI (2006). pp. 93-95. https://kunaifien.files.wordpress.com/2008/12/2006-indonesia-energy-outlookstatistic1.pdf

22. M. Rumbayan, A. Abudureyimu, K. Nagasaka, Renew. Sust. Energ. Rev. 16:1437-1449 (2012).

http://wgbis.ces.iisc.ernet.in/biodiversity/sahyadri enews/newsletter/issue45/bibliograp hy/Mapping $\% 20$ of $\% 20$ solar $\% 20$ energy $\% 20$ potential $\% 20$ in $\% 20$ indonesia $\% 20$ using $\% 2$ 0artifical.pdf

23. A.J. Veldhuis, A.H.M.E. Reinders. Renew. Sust. Energ. Rev., 52:757-769 (2015). https://research.utwente.nl/en/publications/reviewing-the-potential-and-costeffectiveness-of-off-grid-pv-sys 